\title{
SPONTANEOUS KANAMYCIN-RESISTANT ESCHERICHIA COLI MUTANT WITH ALTERED PERIPLASMIC OLIGOPEPTIDE PERMEASE PROTEIN (OPPA) AND IMPERMEABILITY TO AMINOGLYCOSIDES
}

\author{
Mônica B. Rodriguez ${ }^{1 *}$; Sérgio O. P. Costa ${ }^{2}$ \\ ${ }^{1}$ Departamento de Biologia Geral, Instituto de Ciências Biológicas, Universidade Federal de Minas \\ Gerais-UFMG, Belo Horizonte, MG, Brasil. ${ }^{2}$ Departamento de Microbiologia, Instituto de Ciências \\ Biomédicas, Universidade de São Paulo-USP, São Paulo, SP, Brasil
}

Submitted: October 27, 1997; Returned to authors for corrections: February 06, 1998; Approved: April 20, 1999.

\section{SHORT COMMUNICATION}

\begin{abstract}
A spontaneous kanamycin-resistant Escherichia coli mutant, showing cross resistance to five other aminoglycosides and absence of the OppA protein was isolated. $\left[{ }^{3} \mathrm{H}\right]-$ dihydrostreptomycin uptake is reduced in this mutant, implying that the oligopeptide transport system is involved in accumulation of aminoglycosides, although apparently not related with aminoglycoside permeability alteration due to bacterial adaptation to osmotic changes.
\end{abstract}

Key words: aminoglycosides-resistance, Escherichia coli, OppA.

A new class of mutants that show resistance to several aminoglycoside antibiotics has been selected by exposing Escherichia coli and other Gramnegative bacteria to kanamycin in high osmolarity media $(12,13)$. Kashiwagi et al. (6) suggested that the oligopeptide carrier system was involved with slow accumulation phase (EDP-I, ref. 3) of those antibiotics because the introduction of additional copies of the oppA gene increases Escherichia coli susceptibility to aminoglycosides. In fact, some $E$. coli kanamycin resistant mutants show decrease or deficiency of the oligopeptide permease OppA, a periplasmic protein, as found by SDS-PAGE and Western Blotting with the specific antibody (15). Those mutants revert to the kanamycin sensitive phenotype when transformed with the wild-type oppA gene. Two distinct mutants were detected: one carries a nonsense mutation that abolishes translation of OppA and the other one shows a reduction of about one third of the OppA protein translation, although transcriptional levels are about normal (K. Kashiwagi, personal communication). The reduction of OppA synthesis was correlated with reduction of ornithine synthesis and subsequently of polyamine contents, which is important for stimulation of OppA synthesis at the translational level $(5,7)$. We show here that an E. coli mutant lacking OppA is resistant at the same time to different aminoglycosides due to a reduced accumulation of the drug, thus confirming the participation of the oligopeptide transport system

\footnotetext{
* Corresponding author. Mailing address: Av. Antônio Carlos, 6627. CEP 30161-970, Belo Horizonte, MG. Fax: (+5531) $499-2567$. E-mail: monicabr@icb.ufmg.br
} 
in the uptake of several aminoglycosides. We also show that, even lacking OppA, this mutant still responds to the osmolarity effect.

Strain and culturing conditions. The Escherichia coli strain J53 proA met (4) was used. All media components were from Difco Labs. and hydrated with distilled water. Media used: Nutrient Broth (NB) and Nutrient Agar (NA), low osmolarity medium; and high osmolarity L2 medium ( $2 \%$ tryptone, $1 \%$ yeast extract, $1 \% \mathrm{NaCl}$ and $2 \%$ bacto-agar when required). Media osmolarity was measured in an Osmette-Precision Systems Inc. osmometer.

Susceptibility and resistance evaluation. Bacterial overnight cultures were used after 1000 fold dilution to inoculate plates with increasing concentration of antibiotic. After incubation for 24 hours at $37^{\circ} \mathrm{C}$, the minimal inhibitory concentration or the level of resistance were estimated from the resulting growth. The following antibiotics were used: amikacin and kanamycin from Bristol Laboratories, streptomycin (Squibb \& Sons Ltd.) gentamicin (Schering Corp.), neomycin (Lafi Lab.), tobramycin (Eli Lilly \& Co.), dihydrostreptomycin (Fontoura) and $\left[{ }^{3} \mathrm{H}\right]$-dihydrostreptomycin (Amersham).

$\left.{ }^{3} \mathrm{H}\right]$-dihydrostreptomycin uptake measurement. Exponentially growing cells $\left(\mathrm{OD}_{620}=0.5\right)$ were diluted 10 times in the same medium used for growth plus $4,000 \mathrm{cpm} / \mu \mathrm{g}$ of dihydrostreptomycin (at a final concentration of $50 \mu \mathrm{g} / \mathrm{ml}$ ), and incubated at $37^{\circ} \mathrm{C}$ for 30 minutes. Duplicated $1 \mathrm{ml}$ samples were taken at $0,5,10,15,20$ and 30 minutes after culture dilution and kept on ice until filtration on Millipore $0.22 \mu \mathrm{m}$ teflon coated filters (GYWP01300), previously saturated with $1 \mathrm{ml}$ of culture medium plus $1 \mathrm{mg}$ of streptomycin. After sample filtration, filters were washed with $2 \mathrm{ml}$ of culture medium and $3 \mathrm{ml}$ of $3 \%$ $(\mathrm{w} / \mathrm{v}) \mathrm{NaCl}$ and dried at room temperature. Radioactivity was measured using scintillation liquid in a Beckman LS 5000TD scintillation counter. Dihydrostreptomycin uptake was calculated by subtracting background radioactivity and dividing by cpm value obtained by measuring $1 \mathrm{ng}$ of dihydrostreptomycin.

Periplasmic proteins extraction (Ames et al., 1984, modified). Cells from $3 \mathrm{ml}$ of overnight culture were collected by centrifugation at 3,000rpm for 10 minutes at room temperature, resuspended on residual medium, mixed with $40 \mu \mathrm{l}$ of chloroform and incubated for 25 minutes at room temperature. $200 \mu 1$ of $10 \mathrm{mM}$ Tris-HCL pH 8.0 was added and the suspension was centrifuged at 3,000 rpm for 25 minutes at $4^{\circ} \mathrm{C}$. Supernatant was carefully recovered (periplasmic proteins fraction). Protein concentration was measured as in Lowry et al., 1951.

SDS-PAGE and Immunoblotting. 11\% SDSPAGE was performed as in Lugtenberg et al (1975) with modifications: running gel was made by mixing $6.25 \mathrm{ml}$ of $44 \%$ acrilamide $/ 0.8 \%$ bis-acrilamide, $0.5 \mathrm{ml}$ of $10 \%$ SDS, $0.63 \mathrm{ml}$ of $1 \%$ ammonium persulfate, $12 \mathrm{ml}$ of $0.75 \mathrm{M}$ Tris- $\mathrm{HCl} \mathrm{pH} 8.8$ and $5.12 \mathrm{ml}$ of deionized water. Stacking gel was made by mixing $0.5 \mathrm{ml}$ of $44 \%$ acrilamide $/ 0.8 \%$ bisacrilamide, $50 \mu 1$ of $10 \%$ SDS, $0.12 \mathrm{ml}$ of $1 \%$ ammonium persulfate, $2.5 \mathrm{ml}$ of $0.25 \mathrm{M}$ Tris- $\mathrm{HCl}$ pH6.8 and $1.83 \mathrm{ml}$ of deionized water. Polimeration was started by addition of TEMED to $0.02 \%$. After running the gel, proteins were silver stained as in Morrissey (1981) or transferred to nitrocellulose filter in a MultiphorII apparatus (Pharmacia). Western blotting was performed as described in Maniatis et al. (1989) using specific anti-OppA rabbit serum kindly offered by D. D. Santos (Centro de Biotecnologia, UFRGS) diluted 1: 1,000, anti-rabbit IgG peroxidase conjugated diluted 1: 2,500 and diaminobenzidine as chromogenic substrate.

When the aminoglycoside sensitive Escherichia coli $\mathrm{J} 53$ is plated on the high osmolarity medium L2 (448.6 mOsm) containing $20 \mu \mathrm{g} / \mathrm{ml}$ of kanamycin, resistant colonies arise at frequencies around $5 \times 10^{-6}$. One high level kanamycin-resistant clone (A31) was chosen to have its permeability to aminoglycosides examined, in comparison with the original sensitive strain J53. This clone is resistant to $200 \mu \mathrm{g} / \mathrm{ml}$ of kanamycin, streptomycin, tobramycin, gentamicin, amikacin and neomycin when L2 medium is used, and lacks a periplasmic protein (8) that was identified as OppA by Western Blotting (Fig. 1). Given that previous data pointed out to the importance of the medium osmolarity on aminoglycoside susceptibility $(8,9)$, we evaluated the $\left[{ }^{3} \mathrm{H}\right]$-dihydrostreptomycin uptake on NB (63.1 mOsm) and NB plus $0.5 \mathrm{M}$ sorbitol (531.1 mOsm). The resistant mutant showed remarkably reduced antibiotic accumulation (Fig. 2) even in low osmolarity conditions, where the susceptibility is higher (13), thus confirming the mutant impermeability hypothesis as the resistance mechanism. The osmolarity effect on bacterial susceptibility to aminoglycosides has been shown to be present on sensitive bacteria (14) as well as on resistant strains (16), even if the resistance is not related with OppA alteration, but is due to other 


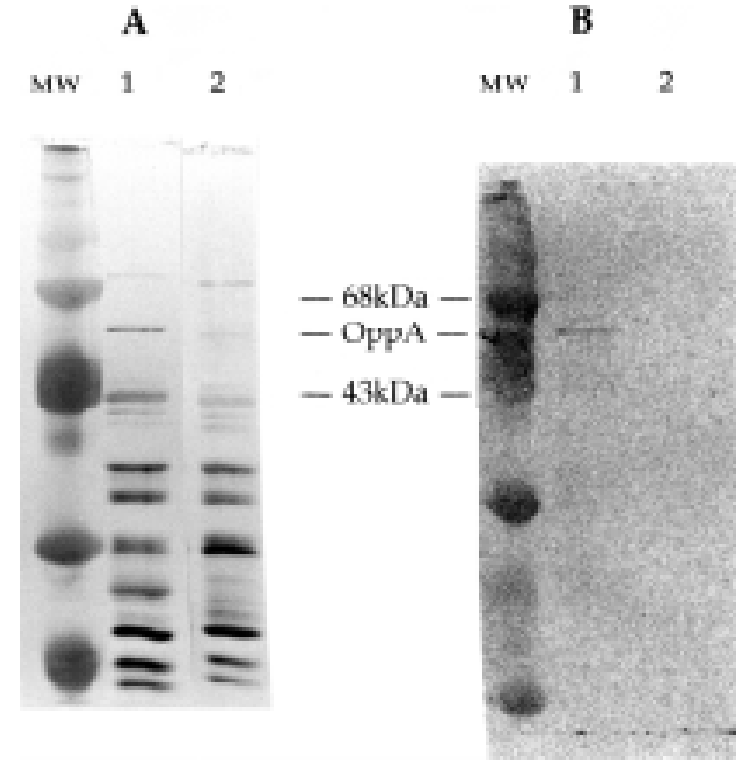

Figure 1. OppA absence on kanamycin resistant mutant. (A) shows a 11\% SDS-PAGE of periplasmic proteins and (B) shows a Western blot using anti-OppA, from the aminoglycoside sensitive strain J53 (lanes 1) and the resistant clone A31 (lanes 2).

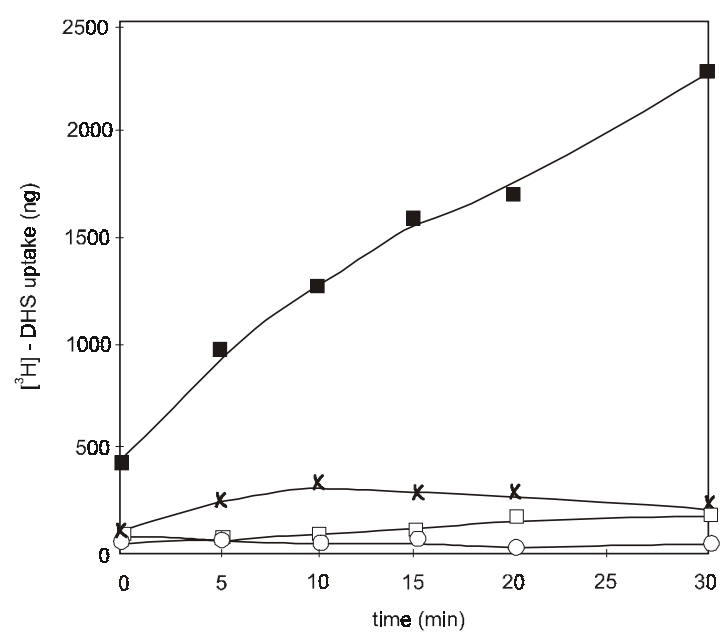

Figure 2. $\left[{ }^{3} \mathrm{H}\right]$-dihydrostreptomycin $\left(\left[{ }^{3} \mathrm{H}\right]\right.$-DHS) uptake by aminoglycoside resistant A31 cells in low osmolarity NB (x) and high osmolarity $\mathrm{NB}+0.5 \mathrm{M}$ sorbitol (o); and by sensitive J53 cells in $\mathrm{NB}$ (filled squares) and $\mathrm{NB}+0.5 \mathrm{M}$ sorbitol (open squares).

mechanisms such as enzymatic inactivation of the drug (1). Our results show that the high osmolarity protective effect is indeed due to a reduction of the bacterial permeability to aminoglycosides. This may be a side effect of a general reduction of permeability for high osmolarity adaptation and rather than a specific one for aminoglycosides. On the other hand, the fact that a spontaneous aminoglycoside resistant mutant, lacking OppA, has reduced permeability to these antibiotics, confirming that the oligopeptide carrier system plays a role on aminoglycoside transport, may represent an important information for antimicrobial therapy, since mutants lacking OppA have recently been isolated from clinical samples (1).

\section{ACKNOWLEDGMENTS}

We thank CNPq and FAPESP for financial support, Maria Beatriz Riveron Acosta for Western blotting experiment, and Luis Carlos Ferreira, Elisabeth Guesnier Azevedo and Ana Clara Schenberg for the critical review of the manuscript.

\section{RESUMO}

\section{Mutante espontâneo de Escherichia coli resistente à canamicina com expressão de oligopeptídeo permease periplasmática (OppA) alterada e impermeabilidade aos aminoglicosídeos}

Um mutante espontâneo de Escherichia coli foi selecionado com canamicina e mostrou resistência cruzada a cinco outros aminoglicosídeos e ausência da proteína OppA. A incorporação de diidroestreptomicina tritiada mostrou-se reduzida nesse mutante, implicando que o sistema de transporte de oligopeptídeos está envolvido na acumulação de aminoglicosídeos, embora aparentemente não esteja relacionado com a alteração de permeabilidade aos aminoglicosídeos decorrente da adaptação bacteriana a mudanças osmóticas.

Palavras-chave: aminoglicosídeos, Escherichia coli, OppA.

\section{REFERENCES}

1. Acosta, M.B.R. Osmodependência e alteração da proteína periplasmática OppA em amostras hospitalares de Escherichia coli resistentes aos aminoglicosídeos. São Paulo, 1997, 41p. (Ms. D. Thesis. Instituto de Ciências Biomédicas. USP).

2. Ames, G.F.L.; Prody, C.; Kustu, S. Simple, rapid and quantitative release of periplasmic proteins by chloroform. J. Bacteriol. 160:1181-1183. 1984. 
3. Bryan, L.E.; van den Elzen, H.M. Effects of membrane-energy mutations and cations on streptomycin accumulation by bacteria: a model for entry of streptomycin and gentamicin in susceptible and resistant bacteria. Antimicrob. Agents Chemother., 12: 163- 177. 1977.

4. Clowes, R.C.; Hayes, W. Experiments in Microbial Genetics. Blackwell Scientific Publications, Oxford and Edinburgh, 1968, 244p.

5. Igarashi, K.; Saisho, T.; Yguchi, M.; Kashiwagi, K. Molecular mechanism of polyamine stimulation of the synthesis of oligopeptide-binding protein. J. Biol. Chem., 272: 4058-4064. 1997.

6. Kashiwagi, K.; Miyaji, A.; Ikeda, S.; Tobe, T.; Saskawa, C.; Igarashi, K. Increase of sensitivity to aminoglycoside antibiotics by polyamine-induced protein (oligopeptidebinding protein) in Escherichia coli. J. Bacteriol., 174: 43314337. 1992.

7. Kashiwagi, K.; Yamaguchi, Y.; Sakai, Y.; Kobayashi, H.; Igarashi, K. Identification of the polyamine-induced protein as periplasmic oligopeptide-binding protein. J. Biol. Chem., 265: 8387-8391. 1990.

8. Lowry, O.H.; Rosenbrough, N.J.; Farr, R.; Randall, R.J. Protein measurement with Folin phenol reagent. J. Biol. Chem. 193: 265-275. 1951.

9. Lugtenberg, B.; Meijers, J.; Peters, R.; van der Hoeck, P.; van Alphen, L. Eletrophoretic resolution of the major outer membrane protein of Escherichia coli K12 into four bands. FEBS Lett. 58: 254-258. 1975
10. Maniatis, T.; Fritsch, E.F.; Sambrook, J. Molecular Cloning: a Laboratory Manual. 2nd ed. CSHL Press, NY. 1989.

11. Morrisey, J.M. Silver stain for proteins in polyacrilamide gels: a modified procedure with enhanced uniform sensitivity. Anal. Biochem. 117: 307-310. 1981.

12. Rodriguez, M.B. Aspectos fisiológicos e genéticos da resistência a antibióticos aminoglicosídeos em bactérias Gram-negativas. São Paulo, 1991, 90p. (Ph.D. Thesis. Instituto de Química. USP).

13. Rodriguez, M.B.; Ferreira, L.C.S.; Monteiro, G.; Costa, S.O.P. Identification of a periplasmic protein associated with osmolarity-dependent aminoglycoside resistance in Escherichia coli. Brazil. J. Genetics, 18: 7-11. 1995.

14. Rodriguez, M.B.; Moysés, L.H.C.; Costa, S.O.P. Effect of osmolarity on aminoglycoside susceptibility in Gramnegative bacteria. Lett. Appl. Microbiol., 11: 77-80. 1990.

15. Tsuhako, M.H. Caracterização de mutantes de Escherichia coli resistentes aos antibióticos aminoglicosídeos: ausência ou decréscimo da proteina ligadora de oligopeptídeos (OppA). São Paulo, 1997, 97p. (Ph.D. Thesis. Instituto de Ciências Biomédicas. USP).

16. Tsuhako, M.H.; Ferreira, L.C.S.; Costa, S.O.P. OppA Escherichia coli mutants are resistant to aminoglycoside antibiotics and are also osmodependent. Gen. Mol. Biol. 21:15-19.1998 